\title{
Front Matter: Volume 11807
}

, "Front Matter: Volume 11807," Proc. SPIE 11807, Liquid Crystals XXV, 1180701 (14 September 2021); doi: 10.1117/12.2606639

Event: SPIE Organic Photonics + Electronics, 2021, San Diego, California, SPIE. United States 


\section{PROCEEDINGS OF SPIE}

\section{Liquid Crystals XXV}

Iam Choon Khoo

Editor

1-5 August 2021

San Diego, California, United States

Sponsored and Published by

SPIE 
The papers in this volume were part of the technical conference cited on the cover and title page. Papers were selected and subject to review by the editors and conference program committee. Some conference presentations may not be available for publication. Additional papers and presentation recordings may be available online in the SPIE Digital Library at SPIEDigitalLibrary.org.

The papers reflect the work and thoughts of the authors and are published herein as submitted. The publisher is not responsible for the validity of the information or for any outcomes resulting from reliance thereon.

Please use the following format to cite material from these proceedings:

Author(s), "Title of Paper," in Liquid Crystals XXV, edited by lam Choon Khoo, Proc. of SPIE 11807 , Seven-digit Article CID Number (DD/MM/YYYY); (DOI URL).

ISSN: 0277-786X

ISSN: 1996-756X (electronic)

ISBN: 9781510644526

ISBN: 9781510644533 (electronic)

Published by

SPIE

P.O. Box 10, Bellingham, Washington 98227-0010 USA

Telephone +1 3606763290 (Pacific Time)

SPIE.org

Copyright @ 2021 Society of Photo-Optical Instrumentation Engineers (SPIE).

Copying of material in this book for internal or personal use, or for the internal or personal use of specific clients, beyond the fair use provisions granted by the U.S. Copyright Law is authorized by SPIE subject to payment of fees. To obtain permission to use and share articles in this volume, visit Copyright Clearance Center at copyright.com. Other copying for republication, resale, advertising or promotion, or any form of systematic or multiple reproduction of any material in this book is prohibited except with permission in writing from the publisher.

Printed in the United States of America by Curran Associates, Inc., under license from SPIE.

Publication of record for individual papers is online in the SPIE Digital Library.

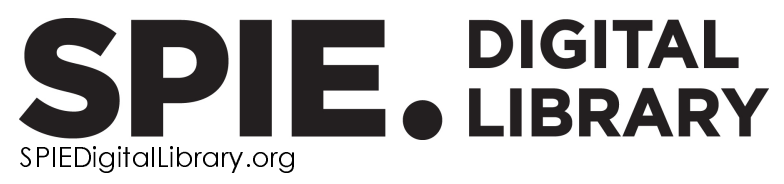

Paper Numbering: A unique citation identifier (CID) number is assigned to each article in the Proceedings of SPIE at the time of publication. Utilization of CIDs allows articles to be fully citable as soon as they are published online, and connects the same identifier to all online and print versions of the publication. SPIE uses a seven-digit CID article numbering system structured as follows:

- The first five digits correspond to the SPIE volume number.

- The last two digits indicate publication order within the volume using a Base 36 numbering system employing both numerals and letters. These two-number sets start with 00, 01, 02, 03, 04, 05, 06, 07, 08, 09, OA, OB ... 0Z, followed by 10-1Z, 20-2Z, etc. The CID Number appears on each page of the manuscript. 


\section{Contents}

NOVEL OPTICAL PROPERTIES AND MANIPULATIONS

1180703 Cholestric bubbles as localized vortices: theory and experiments (Invited Paper) [1 1807-3]

$1180704 \quad$ Polarized beam steering by use of multiply-cascaded rotating polarization gratings with biaxial anisotropy (Invited Paper) [1 1807-4]

PHOTOALIGNMENT, NONLINEAR, AND TUNABLE RESPONSES

1180708 Chirality-enhanced nonlinear optical response of frustrated liquid crystals (Invited Paper)

[11807-7]

NOVEL LIQUID CRYSTALS AND ELECTRO-OPTICS

11807 OF Control of helical-axis orientation of chiral liquid crystals in monodispersed polymer particles (Invited Paper) [1 1807-15]

11807 OG Finger forming optically induced phase transition in dye-doped liquid crystal [1 1807-16]

NEW GENERATION OF CHIRAL OPIICS AND DIFFRACTION OPTICS

11807 OM Single layer, tunable, liquid crystal based Pancharatnam phase devices (Invited Paper) [11807-23]

COLLOIDAL, SEMICONDUCTING LC'S, AND CRYSTAL SYMMETRY ORGANIZATION/TRANSFORMATION

11807 OW Alignment and disorganization of liquid crystals with carbon nanotubes aligning surfaces for novel applications (Invited Paper) [1 1807-32]

LIVE REMOTE KEYNOTE SESSION: ORGANIC PHOTONICS + ELECTRONICS I

11807 OX Photocontrol of selective light reflection by oblique helicoidal cholesteric (Keynote Paper) [11807-1] 
Proc. of SPIE Vol. 11807 1180701-4

Downloaded From: https://www.spiedigitallibrary.org/conference-proceedings-of-spie on 26 Apr 2023
Terms of Use: https://www.spiedigitallibrary.org/terms-of-use 